\title{
Uptake of Amino Acids by Three Species of Nereis (Annelida: Polychaeta). I. Transport Kinetics and Net Uptake from Natural Concentrations
}

\author{
N. O. G. Jørgensen and E. Kristensen \\ Institute of Ecology and Genetics, University of Aarhus, Ny Munkegade, DK-8000 Aarhus C, Denmark
}

\begin{abstract}
Epidermal uptake of alanine, serine and glutamic acid was investigated in salinities of 18 and $32 \% \mathrm{~S}$ in the polychaetes Nereis succinea, $N$. virens and $N$. diversicolor. The three amino acids were chosen because they were the most abundant free, interstitial amino acids in sediment from the sampling locality. Glutamic acid was absorbed at low, but similar rates in the three species in both salinities. In $18 \%$ S, serine was absorbed at equal rates by $N$. succinea and $N$. virens, but a lower uptake occurred in $N$. diversicolor. In $32 \% \mathrm{~S}$, serine uptake increased in all species; the greatest increase was found in $N$. succinea. Alanine was absorbed at almost similar rates in both salinities. The highest uptake occurred in $N$. succinea, followed by $N$. virens and $N$. diversicolor. Uptake kinetics generally demonstrated higher affinities (low $K_{m}$ ) and lower potential uptake rates $\left(V_{\max }\right)$ in 18 than in $32 \% \mathrm{~S}$. The uptake capacity in the three Nereis spp. did not appear to be related to natural interstitial concentrations of amino acids. The most abundant free, intracellular amino acids were taurine, alanine and glycine. In $32 \% \mathrm{~S}$, the proportion of taurine was reduced, compared with $18 \% \mathrm{~S}$. The free amino acid spectrum in the worms was not reflected in capacity or affinity of amino acid uptake. When the Nereis spp. were exposed to natural concentrations of interstitial amino acids, a significant net uptake occurred. Simultaneously, a small quantity of amino acids was released. The magnitude of the uptake from natural concentration levels of amino acids suggests that these nereids obtain a considerable energetic benefit under in-situ conditions.
\end{abstract}

\section{INTRODUCTION}

Marine sediment-inhabiting invertebrates are usually considered to feed exclusively on particles, e.g. bacteria, algae, or larger organisms (e.g. Yonge, 1928). However, a large potential source of food is contained in low-molecular-weight dissolved organic matter in marine sediments (Krom and Sholkovitz, 1977). This dissolved organic matter (DOM) may be important to animals living in the sediment, as most soft-bodied invertebrates are able to absorb small organic molecules through an active, epidermal uptake mechanism (Stephens, 1972; Jørgensen, 1976). Marine polychaetes are thus reported to absorb several species of DOM: Simple sugars (Ahearn and Gomme, 1975); amino acids (Stephens, 1972; Jørgensen, 1979); fatty acids (Testerman, 1972); and hydrocarbons (Lyes, 1979). Other sediment-dwelling organisms like nematodes (Lopez et al., 1979) and pogonophorans (Southward and Southward, 1972, 1979) have also been found to possess significant uptake capacities for
DOM. Mechanisms of ion and osmoregulation have been reviewed comprehensively in 'Marine Ecology', Volume II, by Gilles (1975)

Some authors claim, however, that uptake of DOM from natural concentrations by invertebrates is insignificant as the invertebrates simultaneously release DOM, e.g. as amino acids (Johannes and Webb, 1970), and that bacteria due to their abundance and high substrate affinity, are much more efficient in reducing natural levels of dissolved organics (Hobbie and Webb, 1968; Siebers, 1979). Considering only free, dissolved amino acids in the water, these objections are probably true. However, considering the concentration of free amino acids in interstitial water in shallow coastal sediments (Stephens, 1975; Jorgensen et al., $1980 \mathrm{a}, \mathrm{b})$, the impact of uptake by invertebrates may be of considerable energetic and nutritional importance (Jørgensen, 1980). Yet only a few studies have demonstrated directly a net uptake of interstitial amino acids by invertebrates. Stephens (1975) and Stephens et al. (1978) report that the polychaete Nereis 
diversicolor and the sand dollar Dendraster excentricus are both able to reduce natural sediment concentrations of free amino acids, measured as total primary amines. Reports of uptake of individual amino acids occurring in the interstitial water have not been published, probably due to analytical difficulties.

In the present paper, we demonstrate absorption of specific, interstitial amino acids by three species of Nereis: $N$. succinea Leuckart, $N$. virens (Sars), and $N$ diversicolor (O. F. Müller) - using high-performance liquid chromatography for assay of the amino acids. Among the species investigated, $N$. succinea appears to prefer organic-rich sediments. A high total content of organic matter in marine sediments is generally reflected in high concentrations of dissolved organics (Krom and Sholkovitz, 1977). Therefore, it is expected that $N$. succinea encounters higher concentrations of dissolved organic matter than $N$. virens and $N$. diversicolor and might have evolved high capacities for DOM uptake. This was investigated using the three most abundant interstitial amino acids at the sampling locality (alanine, serine, glutamic acid). The observed uptake rates are compared with concentrations of free interstitial amino acids in the sediment and with the intracellular pools of amino acids in the nereids.

\section{MATERIALS AND METHODS}

Individuals of Nereis succinea, $N$. virens, and $N$. diversicolor were collected from a small, shallow estuary, Kysing Fjord, on the east coast of Jutland, Denmark. The fjord has a length of $3 \mathrm{~km}$ and an area of $1.86 \mathrm{~km}^{2}$. The salinity in the main part of the fjord ranges from 4 to $22 \% \mathrm{~S}$, depending mainly on wind direction (see Muus, 1967, for further details). Animals for experiments were obtained by sieving sediment, while population densities were determined from 3 to 5 cores (area $0.0143 \mathrm{~m}^{2}$, depth $25 \mathrm{~cm}$ ). The distribution of the three Nereis species was investigated along a $450 \mathrm{~m}$ transect beginning at the mouth and heading into Kysing Fjord. In the laboratory, worms for experiments were kept in salinities of 18 or $32 \% \mathrm{~S}$ in aerated aquaria with 5 to $6 \mathrm{~cm}$ of sediment at $15^{\circ} \mathrm{C}$.

Organic matter in the upper $0-5 \mathrm{~cm}$ sediment was determined as loss on combustion at $500^{\circ} \mathrm{C}$ of sediment dried at $105^{\circ} \mathrm{C}$. Undisturbed sediment cores were obtained using acrylic tubes of $4.6 \mathrm{~cm}$ internal diameter and with a length of $25 \mathrm{~cm}$. Interstitial water for experiments and amino acid analysis was extracted from the sediment by centrifugation in small containers (Blackburn, 1979) which were supplied with thick, precombusted glass fiber filters (Gelman Instrument Corp., Michigan, USA). The samples were centrifuged at $500 \mathrm{rpm}$ for $10 \mathrm{~min}$ to minimize disturbance of the sediment (Jørgensen et al., 1980b).
Amino acid uptake experiments with the three Nereis species were carried out with natural seawater which had been stored for 4 to 6 weeks in the dark at $6{ }^{\circ} \mathrm{C}$ prior to use. For the experiments, the salinity was adjusted to 18 or $32 \% \mathrm{~S}$ using a commercial sea salt mixture (Wimex Meeressalz, Krefeld, FRG) and finally the sea water was filtered through $0.45 \mu \mathrm{m}$ pore size filters. Uptake kinetics of alanine, serine, and glutamic acid which are the most common free amino acid in Kysing Fjord sediment (Jørgensen et al., 1980a) were investigated using $\mathrm{L}-\left(\mathrm{U}-{ }^{14} \mathrm{C}\right)$ amino acids (The Radiochemical Centre, Amersham, England) as tracers, and sufficient L ${ }^{12} \mathrm{C}$-amino acids (Sigma Chemical Corp., Missouri, USA) to give final concentrations of 1 , $5,10,20,30,40$, and $60 \mu \mathrm{M}$. At each concentration, 20 worms (wet weights between 20 and $300 \mathrm{mg}$ ) of each species absorbed amino acids in $5 \mathrm{mi}$ medium in 20 separate glass vials. The test temperature was $15^{\circ} \mathrm{C}$. Uptake was measured as change in radioactivity of the solution during the experiment. One-ml samples were taken and $20 \mu \mathrm{l}$ of $1 \mathrm{~N} \mathrm{HCl}$ was added to drive off $\mathrm{CO}_{2}$ $1 \mathrm{~h}$ before counting. The samples were then added to $2.5 \mathrm{ml}$ of Lumagel SB (Lumac Systems, Basel, Switzerland) and counted in a liquid scintillation counter. Quenching was corrected for with internal $\left({ }^{14} \mathrm{C}\right.$ toluene) and external standards.

Uptake rates were calculated according to Jørgensen (1979) using a regression which describes the uptake rate $(Y)$ as a function of the weight $(X): Y=a \cdot X^{b}$ where $a$ is the $y$-intercept, and $b$ the slope of the uptake-weight correlation when plotted in a log-log plot. The use of such regressions are necessary as the relative surface area of the worms decreases with increasing weight. Uptake rates were calculated from individual uptake of the 20 worms of different weights, and rates standardized to $100 \mathrm{mg}$ individuals are given to facilitate direct comparisons of various uptake experiments. Kinetic calculations of the maximum uptake rate, $V_{\text {maxt }}$ and the half-saturation constant, $K_{m}$, of the amino acids were determined from Eadie-Hofstee plots (Lehninger, 1972).

Natural interstitial amino acids were extracted from sediment samples collected from Kysing Fjord on 16 February 1980. After extraction, the interstitial water was filtered through $0.22 \mu \mathrm{m}$ pore size filters and stored at $-20^{\circ} \mathrm{C}$ until use. Three individuals of each Nereis species were exposed to $6 \mathrm{ml}$ of this interstitial water in separate vials at $15^{\circ} \mathrm{C}$. The concentration of specific amino acids was then followed at regular intervals, by taking samples of $0.2 \mathrm{ml}$.

Release of amino acids by the nereids was investigated in sea water made from the commercial sea salt mixture dissolved in redistilled water. The artificial sea water initially contained $0.514 \mu \mathrm{M}$ of amino acids due to impurities in the sea salt. Three worms of each 
species were rinsed in this water twice, blotted for a few seconds, and then placed in separate glass vials containing $6 \mathrm{ml}$ of the aritificial sea water. Samples of $0.2 \mathrm{ml}$ were taken from these vials at regular intervals for analysis of amino acids. The test temperature was $15^{\circ} \mathrm{C}$.

The free intracellular pools of amino acids in the worms were extracted in $80 \%$ reagent grade ethanol (Merck, Darmstadt, FRG) according to Anderson and Bedford (1973). Three individuals of each species were extracted for $24 \mathrm{~h}$. Initially, a gentle ultrasonic treatment was applied. At the end of the extraction, the extracts were centrifuged to precipitate particulate matter and 4 or $8 \mu \mathrm{l}$ of the extracts were used for analysis of amino acids.

In one set of experiments, a Micron (Micron, USA) flow-meter supplied with an electromagnetic flowprobe was used for measurements of ventilation rates. A $210 \mathrm{mg}$ individual of Nereis virens was placed in the flow cell (a plastic tube with an internal diameter slightly larger than the width of the worm, connected to an electromagnetic flow-probe) in $1 \mu \mathrm{M}$ solutions of
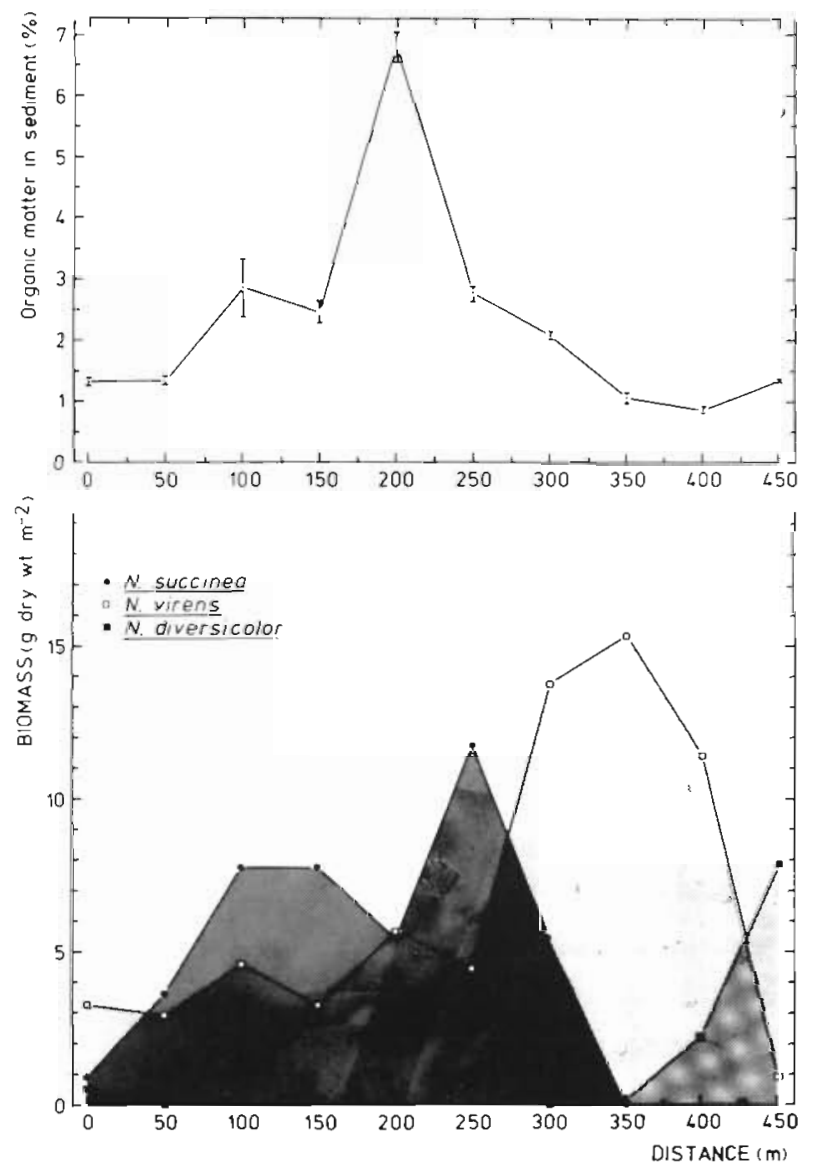

Fig. 1. Nereis succinea, $N$, virens, $N$. diversicolor. Distribution along a transect from the mouth and $450 \mathrm{~m}$ into Kysing Fjord. Organic matter values expressed as means $\pm S$. D. of 3 samples. Material collected June, 1979 alanine, serine, or glutamic acid at $15^{\circ} \mathrm{C}$ and $18 \% \mathrm{~S}$. ${ }^{14} \mathrm{C}$-amino acids were used as tracers. When the worm was actively ventilating, the amino acid concentration in water which had passed the body of the worm, was measured.

The oxygen consumption of the polychaetes was measured using either Winkler procedure (Strickland and Parsons, 1972), or an oxygen electrode (Radiometer E 5046; Radiometer, Copenhagen, Denmark).

Individual amino acids were measured as o-phthaldialdehyde derivatives by reversed phase high-performance liquid chromatography (HPLC) using methanol-buffer gradients (Lindroth and Mopper, 1979). The derivatives were quantified fluorometrically in an Aminco Fluorocolorimeter (American Instrument Company, Maryland, USA) supplied with a selfconstructed $5 \mu$ flow cell of Pyrex glass, and with a primary filter of $340-390 \mathrm{~nm}$ and a secondary cut-off filter of $418 \mathrm{~nm}$. O-phthaldialdehyde (Merck, Darmstadt, FRG) does not react with proline or hydroxyproline, but reacts with ammonium. A Sigma calibration amino acid solution was used as a standard.

In the following, international three-letter symbols for amino acids are used as abbreviations. In addition, these symbols are used: ABA (amino-butyric acid), cit

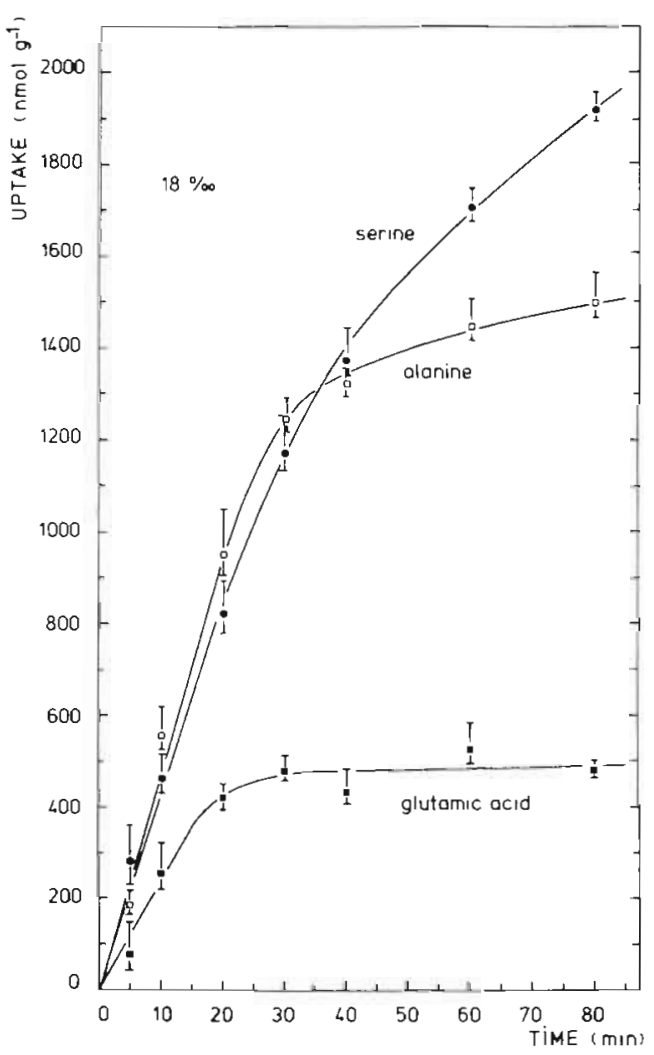

Fig. 2. Nereis diversicolor. Uptake of $10 \mu \mathrm{M}$ serine, alanine, and glutamic acid as a function of time. Data expressed as means $\pm S$. $D$ 
(citrulline), DAPA (diaminopimelic acid), orn (ornithine), and tau (taurine). All weights of the animals are given as wet weights, exept in Figure 1 , where dry weight of the biomass is used.

\section{RESULTS}

\section{Natural Distribution of Nereis spp. in Kysing Fjord}

The occurrence of Nereis succinea coincides with that of a Mytilus edulis flat characterized by a high organic content in the sediment, while $N$. diversicolor is the only Nereis species in the main part of the estuary; outside these areas, $N$. virens prevails (Fig. 1).

\section{Uptake Kinetics of Serine, Alanine, and Glutamic Acid in Nereis spp.}

In preliminary studies, each Nereis species absorbed serine, alanine, and glutamic acid for increasing periods of time from $10 \mu \mathrm{M}$ solutions. The uptake of glutamic acid by $N$. diversicolor suggests that this species has a limited uptake capacity for glutamic acid, as the uptake stabilized after 20 min (Fig. 2); the

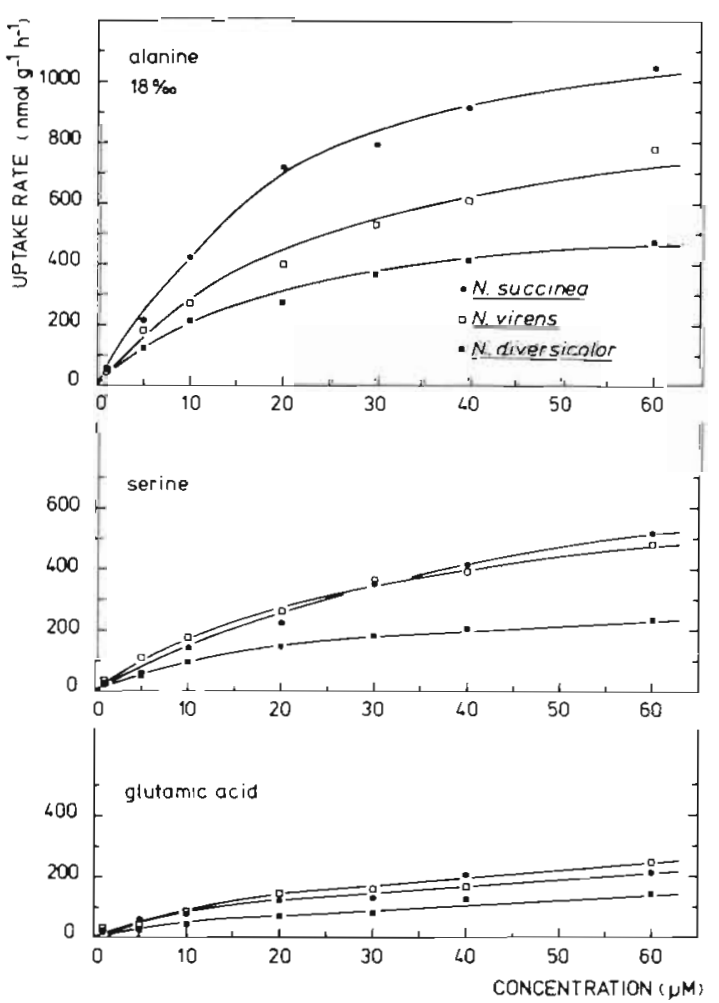

Fig. 3. Nereis succinea, $N$ virens, $N$. diversicolor. Uptake of alanine, serine, and glutamic acid as a function of concentration in $18 \% \mathrm{~S}$. Average coefficient of correlation of linear regressions: $0.87 \pm 0.08($ Mean $\pm \mathrm{S}$. $\mathrm{D}$; $\mathrm{n}=63$ ) absorption of serine and alanine was considerably larger and no stabilization occurred. Similar results were found in $N$. virens and $N$. succinea. In order to facilitate a comparison of alanine, serine, and glutamic acid uptake by the three species, an incubation time of 15 min was chosen as the uptake was linear within this period.

Uptake rates of alanine, serine and glutamic acid demonstrated that the Nereis spp. tested have larger capacities for uptake of alanine and serine than of glutamic acid. In a salinity of $18 \%$, alanine was absorbed fastest by $N$. succinea, followed by $N$. virens and $N$. diversicolor (Fig. 3). Serine was absorbed most slowly by $N$. diversicolor; faster, but similar rates occurred in $N$. virens and $N$. succinea. Uptake of glutamic acid was similar for all 3 species. In $32 \% \mathrm{~S}$ (Fig. 4), uptake rates were comparable to those found in $18 \% \mathrm{~S}$, except that uptake of serine had increased in all species. The most significant increase was observed in $N$. succinea in which uptake increased from $550 \mathrm{nmol} \mathrm{g}^{-1} \mathrm{~h}^{-1}$ in $60 \mu \mathrm{M}$ and $18 \% \mathrm{~S}$, to $1200 \mathrm{nmol} \mathrm{g}^{-1} \mathrm{~h}^{-1}$ in $60 \mu \mathrm{M}$ and $32 \% \mathrm{~S}$. Similarly, the

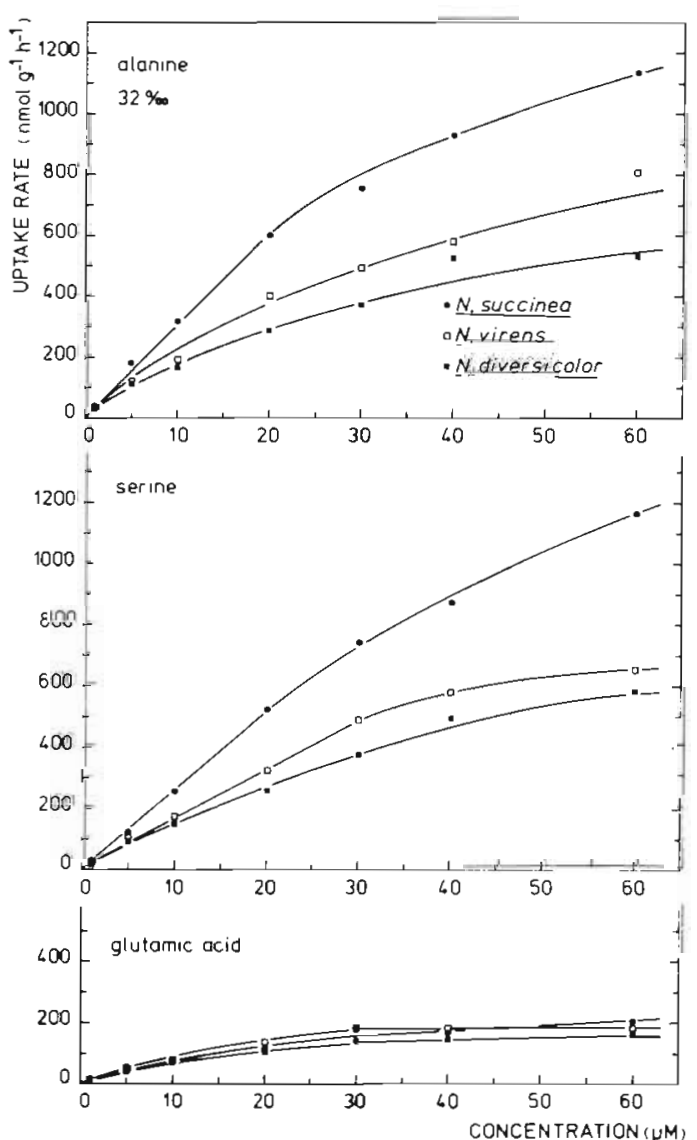

Fig. 4. Nereis succinea, $N$. virens, $N$. diversicolor. Uptake of alanine, serine, and glutamic acid as a function of concentration in $32 \% \mathrm{~S}$. Average coefficient of correlation of linear regressions: $0.84 \pm 0.11$. (Mean $\pm S$. D. $n=63$ ) 
Table 1. Nereis succinea, $N$. virens, $N$. diversicolor. Maximum uptake rate, $V_{\text {max }}$ and half-saturation constant, $K_{m}$, of alanine, serine, and glutamic acid at 18 and $32 \% \mathrm{~S}$. Calculated from uptake rates in Figures 3 and 4 . Coefficients of correlation of the Eadie-Hofstee plots were: $0.93 \pm 0.07(18 \%$ S) and $0.92 \pm 0.06(32 \%$ S) (Means \pm s.d.)

\begin{tabular}{|c|c|c|c|c|c|c|c|}
\hline \multirow{2}{*}{$\begin{array}{c}\text { Salinity } \\
(\% 0)\end{array}$} & \multirow[t]{2}{*}{ Amino acid } & \multicolumn{2}{|c|}{$N$ succinea } & \multicolumn{2}{|c|}{ N. virens } & \multicolumn{2}{|c|}{ N. diversicolor } \\
\hline & & $\frac{V_{\max }}{\mathrm{nmol} \mathrm{g}^{-1} \mathrm{~h}^{-1}}$ & $\frac{K_{m}}{\mu \mathrm{M}}$ & $\frac{V_{\max }}{\mathrm{nmol} \mathrm{g}^{-1} \mathrm{~h}^{-1}}$ & $\frac{K_{m}}{\mu \mathrm{M}}$ & $\frac{V_{\max }}{\mathrm{nmol} \mathrm{g}^{-1} \mathrm{~h}^{-1}}$ & $\frac{K_{m}}{\mu \mathrm{M}}$ \\
\hline \multirow{3}{*}{18} & Alanine & 1504 & 26 & 900 & 20 & 604 & 20 \\
\hline & Serine & 1090 & 67 & 655 & 25 & 344 & 28 \\
\hline & Glutamic acid & 370 & 37 & 267 & 18 & 200 & 35 \\
\hline \multirow{3}{*}{32} & Alanine & 2320 & 61 & 1631 & 68 & 743 & 30 \\
\hline & Serine & 2765 & 84 & 1535 & 72 & 1458 & 87 \\
\hline & Glutamic acid & 273 & 24 & 317 & 32 & 243 & 22 \\
\hline
\end{tabular}

uptake rates of $N$. diversicolor increased from 220 to $600 \mathrm{nmol} \mathrm{g} \mathrm{g}^{-1} \mathrm{~h}^{-1}$ while a minor increase occurred in $N$. virens. Uptake of glutamic acid did not differ from that in $18 \% \mathrm{~S}$.

The uptake kinetics generally demonstrated higher substrate affinities in 18 than in $32 \% \mathrm{~S}$. In $18 \% \mathrm{~S}$, the transport constants $\left(K_{m}\right)$ were similar, except that the serine affinity is low in $N$. succinea and that $N$. virens has a high affinity for glutamic acid (Table 1). In $32 \%$ S, the $K_{m}$ of alanine and especially those of serine have increased, in contrast to the $K_{m}$ of glutamic acid which were slightly reduced. The transport constants of serine demonstrate that a high uptake rate need not be reflected in a high affinity.

\section{Free Amino Acids in the Sediment Inhabited by Nereids}

The concentration of free amino acids in the 0-4 and $4-8 \mathrm{~cm}$ sediment from typical Nereis succinea and $N$. virens localities did not differ significantly, though

Table 2. Concentration of free amino acids in sediment from typical Nereis succinea and $N$. virens localities. Concentrations in nM. Sediment cores sampled at Jan. $18,1980,1.3^{\circ} \mathrm{C}$. Results expressed as means of 6 cores. Standard deviations given for total concentrations. - not detected. Amino acids presented in elution order

\begin{tabular}{|c|c|c|c|c|}
\hline \multirow[t]{2}{*}{ Amino acid } & \multicolumn{2}{|c|}{ N. succinea sediment } & \multicolumn{2}{|c|}{$N$. virens sediment } \\
\hline & $0-4 \mathrm{~cm}$ & $4-8 \mathrm{~cm}$ & $0-4 \mathrm{~cm}$ & $4-8 \mathrm{~cm}$ \\
\hline Aspartic acid & 252 & 831 & 883 & 1176 \\
\hline Glutamic acid & 222 & 1054 & 789 & 3532 \\
\hline Aspartate & 112 & 239 & 493 & 2679 \\
\hline Serine & 621 & 799 & 755 & 524 \\
\hline Glutamate & 53 & 287 & 245 & 478 \\
\hline Histidine & 116 & 208 & 222 & 665 \\
\hline Citrulline & 40 & 83 & 86 & 80 \\
\hline Threonine & 110 & 358 & 193 & 263 \\
\hline Glycine & 381 & 2571 & 660 & 735 \\
\hline Arginine & 44 & 354 & 248 & 601 \\
\hline Taurine & - & 160 & - & 165 \\
\hline$\beta$-alanine & 23 & 536 & 106 & 254 \\
\hline Tyrosine & 50 & 323 & 107 & 169 \\
\hline Alanine & 203 & 2011 & 383 & 1904 \\
\hline$\gamma-\mathrm{ABA}$ & 30 & 77 & 112 & 164 \\
\hline$\alpha-\varepsilon-D A P A$ & - & - & 108 & 198 \\
\hline$\alpha-\mathrm{ABA}$ & - & 56 & 42 & 28 \\
\hline Tryptophane & 51 & 86 & 341 & 269 \\
\hline Methionine & 231 & 230 & 87 & 139 \\
\hline Valine & 98 & 486 & 123 & 204 \\
\hline Phenylalanine & 43 & 151 & 66 & 105 \\
\hline Isoleucine & 57 & 236 & 107 & 139 \\
\hline Leucine & 1294 & 1483 & 174 & 477 \\
\hline Ornithine & 897 & 1141 & 420 & 647 \\
\hline Lysine & 288 & 367 & 101 & 120 \\
\hline Total & $5198 \pm 636$ & $14092 \pm 4352$ & $6727 \pm 2006$ & $15545 \pm 5407$ \\
\hline
\end{tabular}


slightly higher mean concentrations occurred in the $N$. virens sediment (Table 2). The concentration of glutamic acid was somewhat higher in the $N$. virens sediment, but the concentrations of serine and alanine were similar. The data do not indicate that $N$. succinea is exposed to higher concentrations of amino acids.

\section{Free Extractable Amino Acids (FEAA) in the Nereids}

Free amino acids are important osmotic effectors in tissues of most marine invertebrates (Gilles, 1975). The concentration of FEAA in the Nereis spp. may therefore be reflected in the uptake capacity of specific amino acids since absorbed amino acids act as FEAA (Jørgensen, 1979).

The total amounts of FEAA increased in all species when the salinity changed from 18 to $32 \%$ (Fig. 5). The amino acids appear to be quantitatively more important in $32 \% \mathrm{~S}$ than in $18 \% \mathrm{~S}$, since the pools increased an average of $216 \%$ in the three species while the salinity increased only $78 \%$. The highest amounts of FEAA were found in Nereis succined in both salinities. In all species glycine, taurine, and alanine made up the main portion of the FEAA. Interestingly, in $18 \% \mathrm{~S}$ the percentage of taurine exceeded that of alanine, but in $32 \% \mathrm{~S}$ alanine was more important than taurine.

The FEAA pools are not directly related to uptake kinetics: (1) The increased importance of alanine as a FEAA in $32 \% \mathrm{~S}$ is not reflected in a higher uptake rate or in a low $K_{m}$-value. (2) The increased uptake of serine in all three species in $32 \% \mathrm{~S}$ is not explained by a larger requirement for this amino acid as a free intracellular amino acid. (3) In $18 \%$ S glutamic acid constituted $9 \%$ of the FEAA in Nereis diversicolor, but the uptake kinetics show that this species has an extremely low uptake of glutamic acid in $18 \% \mathrm{~S}$. The higher uptake rate of alanine (in 18 and $32 \%$ S) and of serine (in $32 \%$ S) in $N$. succinea may be found in the twofold larger pools of FEAA in this species, compared with $N$. virens and $N$. diversicolor.

\section{Uptake of Natural Interstitial Amino Acids}

When individuals of Nereis succinea, $N$. virens, and $N$. diversicolor were placed in Kysing-sediment pore water, a fast initial reduction in the total concentration of amino acids was observed; then the reduction declined (Figs 6, 7, 8). After $20 \mathrm{~h}$, however, the total concentration had increased, compared with the 8-h concentrations. The concentration of individual amino acids (Table 3 , Figs $6,7,8$ ) reveals that both uptake and release of amino acids determined the total concentrations. In the first $8 \mathrm{~h}$, the most abundant amino acids were typically absorbed, though an increase of some of these amino acids occurred after $2 \mathrm{~h}$ in $N$. virens. After $20 \mathrm{~h}$, release had increased the concentration of some amino acids, e.g. ornithine, while others were still reduced.
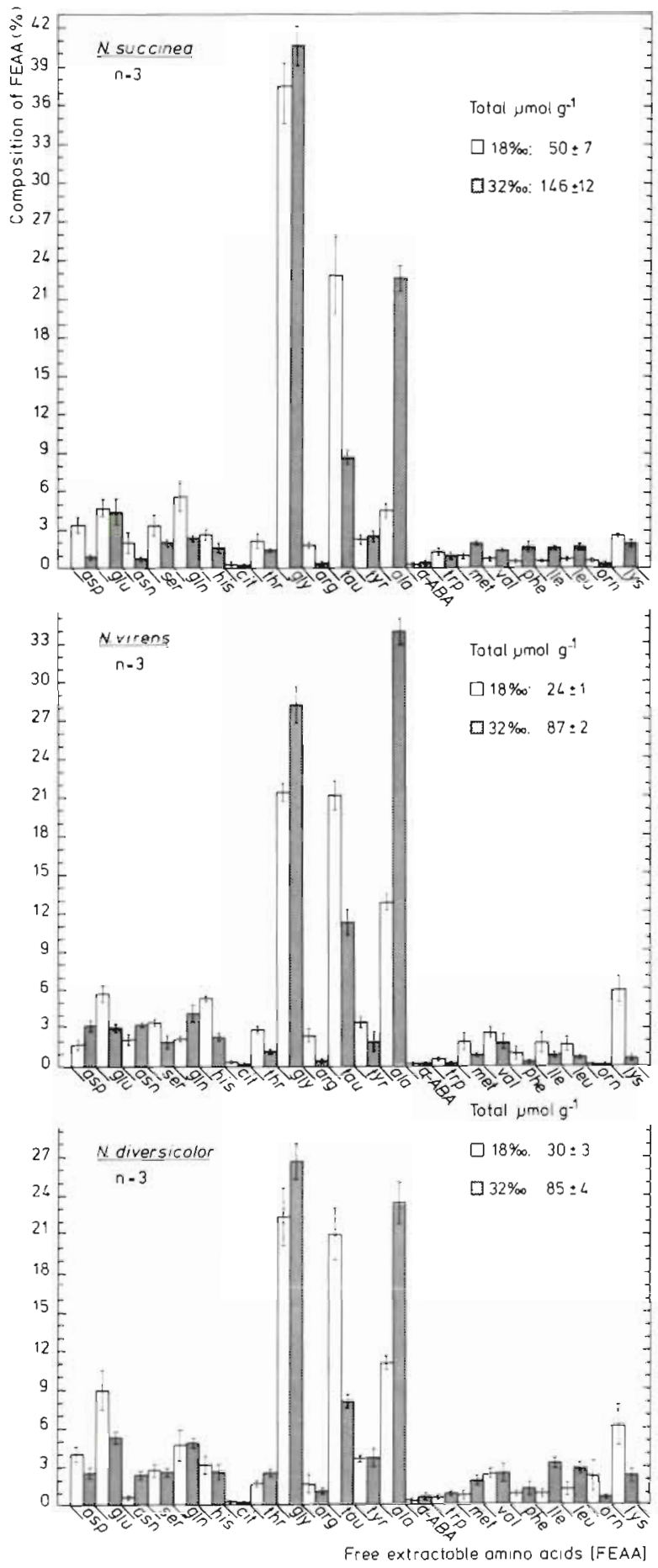

Fig. 5. Nereis succinea, $N$ virens, $N$. diversicolor Composition of free extractable amino acids (FEAA) in 18 and $32 \% \mathrm{~S}$. Data expressed as means \pm S. D., indicated by the error bars. Amino acids presented in elution order 


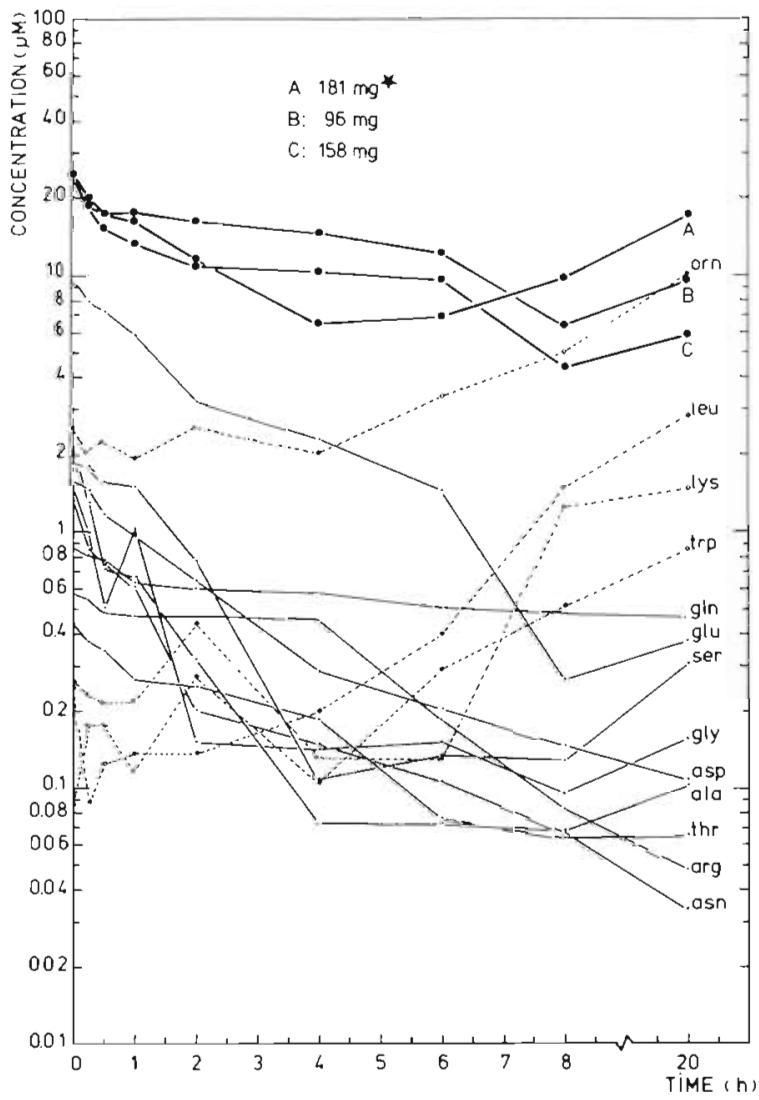

Fig. 6. Nereis succinea. Uptake of natural interstitial amino acids. Heavy lines: total concentrations. Concentration of individual amino acids shown for individual marked with star. Thin lines: amino acids mainly absorbed; dotted lines: amino acids mostly released

The uptake rates of alanine and serine by the three species of Nereis were similar to rates predicted from the Michaelis-Menten equation $\left(V=V_{\max } \cdot S\right.$ ) $K_{m}+S$, where $V$ is the actual uptake rate and $S$ amino acid concentration), using values for $K_{m}$ and $V_{\max }$ from Table 1, but the actual rate of glutamic acid was higher than the calculated rate. Thus, the $124 \mathrm{mg}$ individual of $N$. virens (Fig. 7) had an actual uptake rate of $340 \mathrm{nmol} \mathrm{g}^{-1} \mathrm{~h}^{-1}$ from the initial concentration of $9.554 \mu \mathrm{M}$ while the calculated uptake rate predicts a rate of $93 \mathrm{nmol} \mathrm{g}^{-1} \mathrm{~h}^{-1}$.

Glutamate and arginine were absorbed to minor extents, but after $4-6 \mathrm{~h}$, the concentrations decreased abruptly (Figs 6, 7,8). This sudden decrease was probably caused by bacterial assimilation. A similar decline occurred in several other amino acids after 4-6 h, also indicating that bacteria may have proliferated.

Simultaneously with the uptake, amino acids were released from the polychaetes, as the concentrations of some amino acids mainly increased during the experiments. Individual variations in released amino acids occurred, but ornithine was generally the most com-

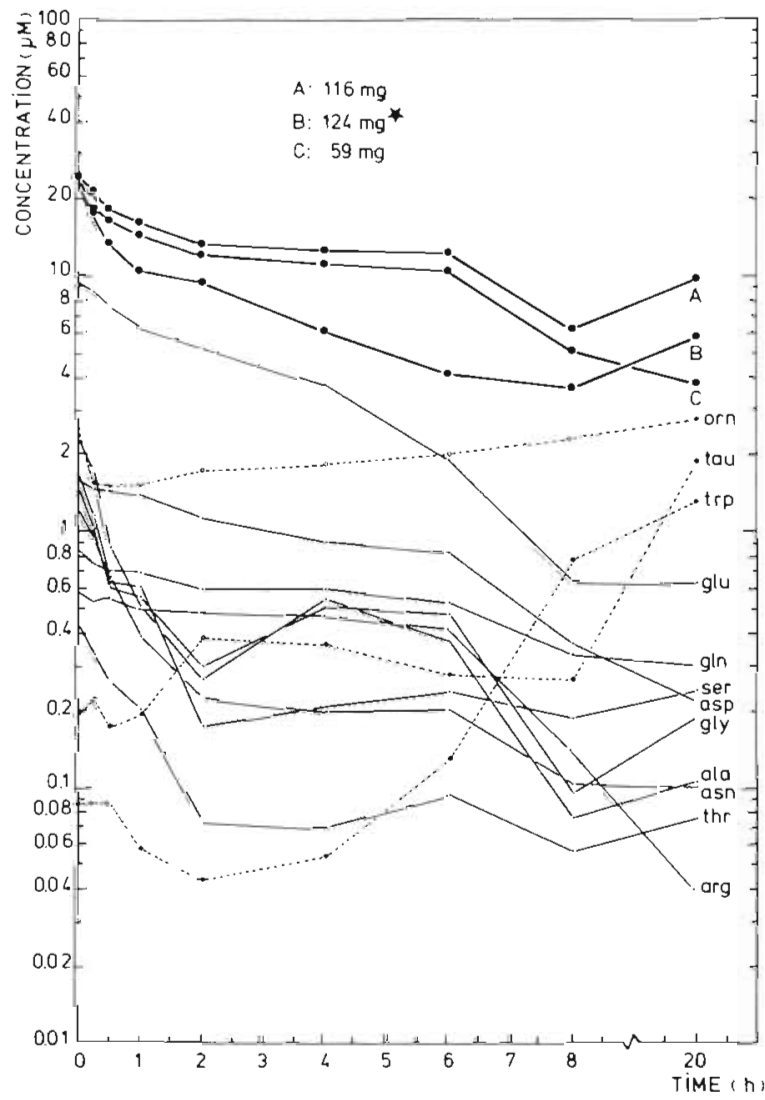

Fig. 7. Nereis virens. Otherwise as legend to Figure 6

mon. Lysine, leucine, tryptophane, or valine accumulated in other experiments. Other amino acids may have been released but absorbed by the worms or by bacteria.

\section{Release of Free Amino Acids from the Nereids}

When the worms were placed in artificial sea water, there was little change in the total concentrations of amino acids at first, but after $1 \mathrm{~h}$ a slow increase began which continued throughout the rest of the experiment (Fig. 9). This was caused by uptake and release of various amino acids as indicated in the amino acid spectrum in the Nereis succinea experiment. The total concentrations slowly increased to about $1 \mu \mathrm{M}$ at $4 \mathrm{~h}$, and after $21 \mathrm{~h}$ concentrations from $2.3 \mu \mathrm{M}$ ( $N$. diversicolor) to $8.5 \mu \mathrm{M}$ ( $N$. virens) were found in the vials. Ornithine dominated in most of the samples, but lysine and leucine were also abundantly released amino acids. Figure 9 suggests that release of amino acids is merely related to the weight of the worms rather than to the species. The importance of bacteria was not determined.

The low concentrations of most amino acids in Figure 9 might be due to fast uptake of released amino 
acids by the worms, thus indicating dynamic steadystate concentrations and not actual release. This was investigated in Nereis virens using $0.100 \mu \mathrm{M}$ concentrations of alanine, serine, and glutamic acid, respectively, in artificial sea water. ${ }^{14} \mathrm{C}$-amino acids were used as tracers. Assuming unchanged specific activity, the average concentration of the added amino acids was $0.059 \mu \mathrm{M}$ after $4 \mathrm{~h}$, while the total concentration of alanine, serine, and glutamic acid, respectively, was $0.087 \mu \mathrm{M}$ (determined with HPLC). This shows that amino acids simultaneously were absorbed and released. It should be noted, however, that the two processes probably proceed independently.

\section{Energetic Importance of Uptake of Natural Interstitial Amino Acids}

As amino acids absorbed by Nereis spp. participate in catabolic pathways of the worm (Jørgensen, 1979), it is reasonable to compare to energy obtained from absorption of amino acids with the respiratory expenditure of the worms. Accumulation of interstitial amino acids was calculated as difference in total concentration, initially and after 30 min of uptake, from Figures

Table 3. Concentration of free interstitial amino acids in sediment from Kysing Fjord. Pore water from the upper $10 \mathrm{~cm}$ of sediment was extracted from cores collected at Febr. 7 , 1980. $0.7^{\circ} \mathrm{C}$. Concentrations in nM. Amino acids given in elution order

\begin{tabular}{|lc|}
\hline Amino acid & Concentration (nM) \\
\hline Aspartic acid & 1592 \\
Glutamic acid & 9554 \\
Aspartate & 1242 \\
Serine & 1658 \\
Glutamate & 866 \\
Histidine & 351 \\
Citrulline & 116 \\
Threonine & 448 \\
Glycine & 1522 \\
Arginine & 567 \\
Taurine & 195 \\
B-alanine & 175 \\
Tyrosine & 406 \\
Alanine & 2351 \\
Y-ABA & 184 \\
a-ABA & 30 \\
Tryptophane & 86 \\
Methionine & 92 \\
Valine & 323 \\
Phenylalanine & 176 \\
Isoleucine & 178 \\
Leucine & 249 \\
Ornithine & 2153 \\
Lysine & 263 \\
Total & 24777 \\
& \\
& \\
&
\end{tabular}

6, 7, and 8. Respiration rates of both resting and actively ventilating worms were used (E. Kristensen, in preparation). Energy obtained from absorbed amino acids was related to the respiration assuming that the complete oxidation of a mixture of amino acids requires $1.24 \mu \mathrm{g} \mathrm{O}_{2} \mu \mathrm{g}^{-1}$ amino acid (Stephens, 1975). The calculations (Table 4 ) show that resting worms are provided with sufficient energy to cover the total respiratory energy requirement (perhaps not totally in $N$. succinea) by absorption of interstitial amino acids. When the worms are ventilating, the energetic benefit decreases, but a substantial energetic gain is still achieved.

\section{Uptake of Amino Acids by Nereis virens in a Flow Cell}

When a $210 \mathrm{mg}$ individual of Nereis virens was placed in $1.0 \mu \mathrm{M}$ solutions of alanine, serine, and glutamic acid, respectively, in a flow cell, the amino acids were reduced to $0.816 \mu \mathrm{M}$ (alanine), $0.855 \mu \mathrm{M}$ (serine), and $0.923 \mu \mathrm{M}$ (glutamic acid) at a ventilation rate of $1.0 \mathrm{ml} \mathrm{min}{ }^{-1}$. The experimental setup is comparable to in-situ conditions of Nereis species (Muus, 1967) and demonstrates that ventilation may supply the worms with both oxygen and dissolved organic matter.

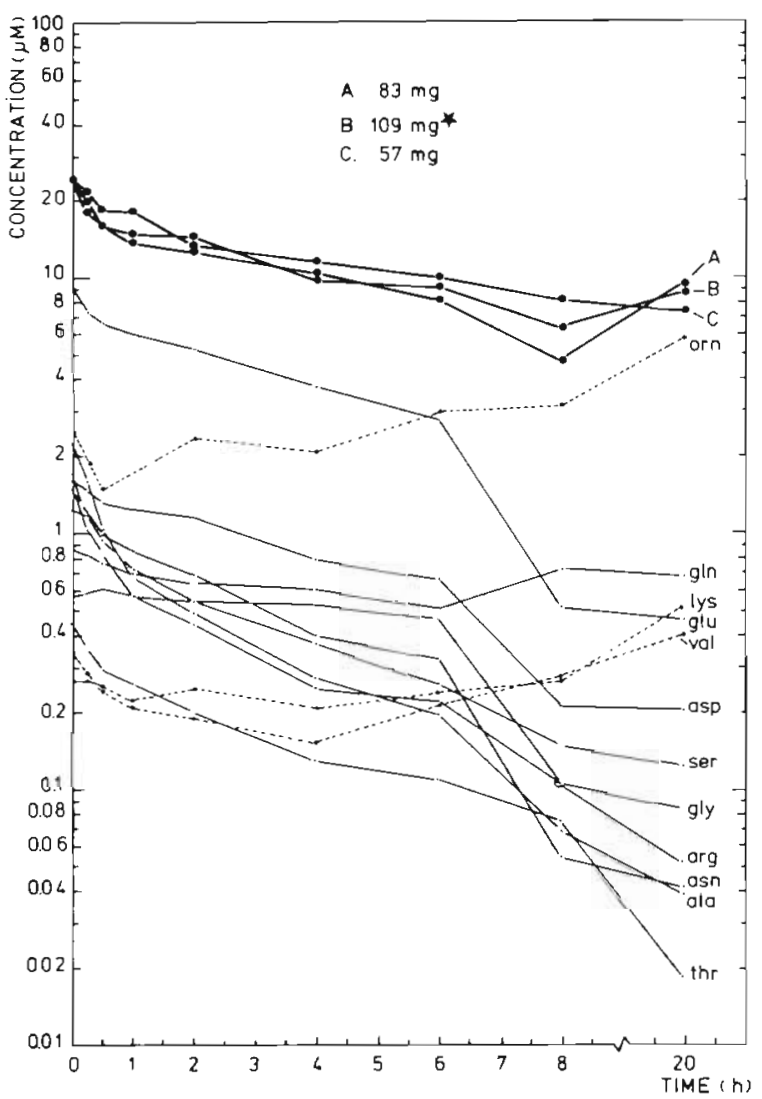

Fig. 8. Nereis diversicolor. Otherwise as legend to Figure 6 
Table 4. Nereis succinea, $N$. virens, and $N$. diversicolor. Energetic significance of uptake of natural interstitial amino acids as shown in Figures 6, 7, and 8. Absorbed amino acids determined during initial 30 min of uptake. Respiration rates of resting worms measured individually in $50 \mathrm{ml}$ bottles while respiration rates of ventilating individuals were determined in tubes connected to a flowmeter Resprration of each ventilating worm based on 5 replicates. $18 \% \mathrm{~S}_{i} 15^{\circ} \mathrm{C}$

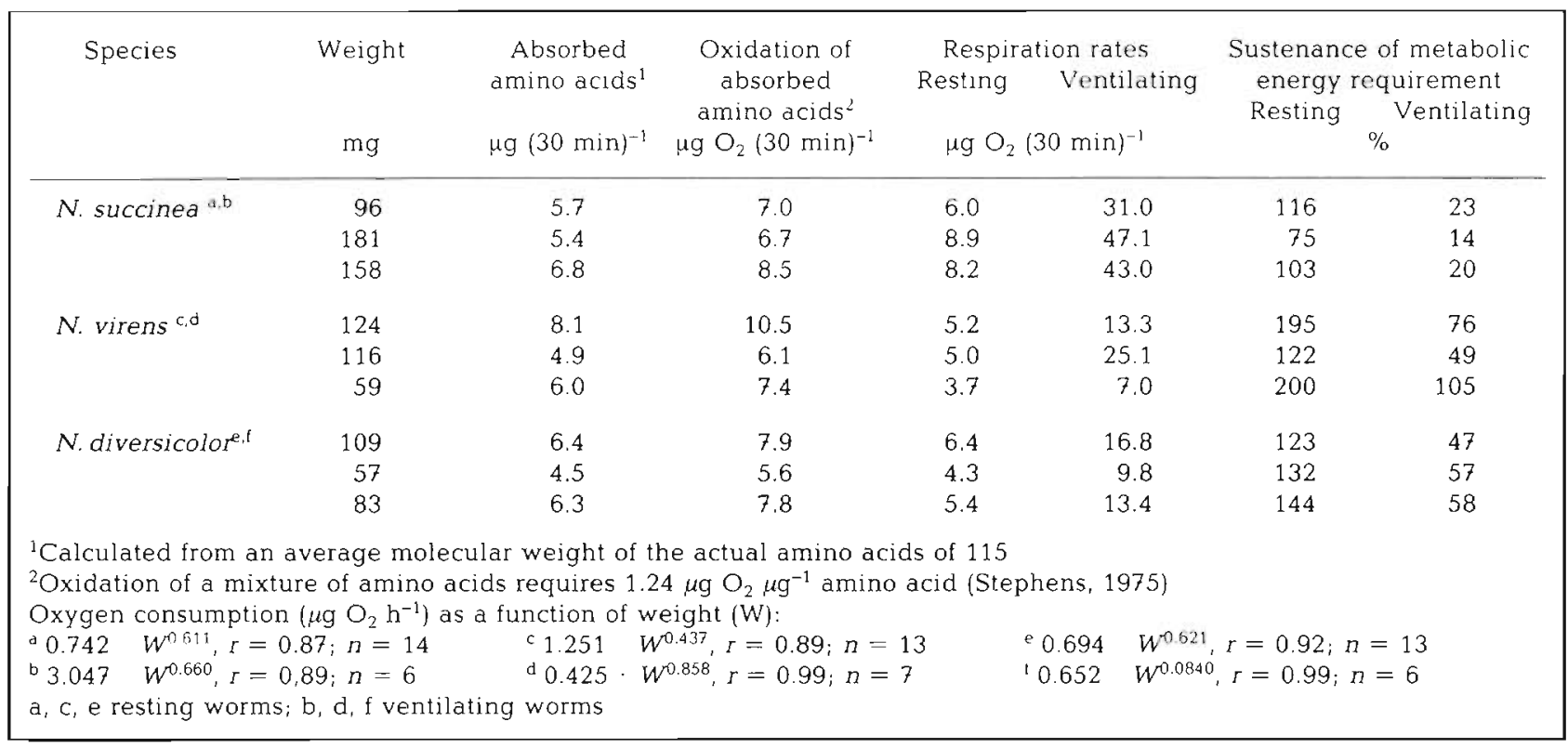

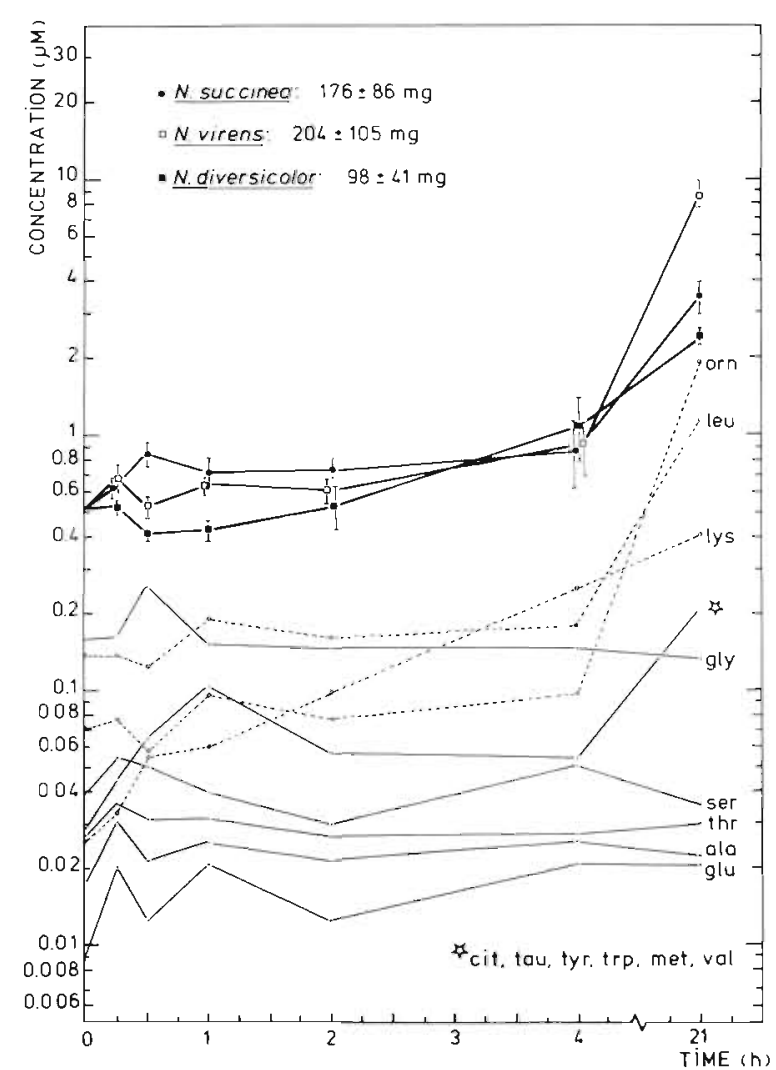

Fig. 9. Nereis succinea, N. virens, $N$. diversicolor. Release of free amino acids. Heavy lines: total concentrations. Data expressed as means \pm S. D. Concentration of individual amino acids shown for a $160 \mathrm{mg}$ N. succinea. Dotted lines: most abundant released amino acids; thin lines: concentration of remaining amino acids

\section{DISCUSSION}

The natural distribution of the Nereis species in Kysing Fjord (Fig. 1) can probably be explained by an increased tolerance to changes in salinity, including extremely low salinities, in $N$. diversicolor (Smith, 1955; Neuhoff, 1979), and by an increased tolerance to low oxygen tensions and presence of $\mathrm{H}_{2} \mathrm{~S}$ in the rich sediments, in $N$. succinea (Theede et al., 1973). In more stable salinities and in more sandy sediments with a low organic content, $N$. virens appears to possess competitive advantages. The present observations are in agreement with Theede et al. (1973) who studied Nereis spp. in Kiel Bay.

The 3 Nereis species are typical marine invertebrates in terms of qualitative amino acid uptake. In kinetic studies, higher uptake rates of neutral than of acidic amino acids, especially of glutamic acid, are generally reported (Stephens, 1964; Taylor, 1969; Stephens, 1975; Stephens et al., 1978; Southward and Southward, 1979). However, differences in both capacity and affinity of amino acid uptake were observed in $N$. succinea, $N$. virens, and $N$. diversicolor. $N$. diversicolor had low uptake rates but high affinities of alanine, serine and glutamic acid, in contrast to $N$. succinea which demonstrated high uptake rates and low affinities. Intermediate uptake rates occurred in $N$. virens while the amino acid affinity was higher in $18 \% \mathrm{~S}$ than in $32 \% \mathrm{~S}$.

The absorption rate of alanine and glutamic acid in all 3 species was slightly influenced by salinity 
whereas the serine uptake increased when the salinity was changed from 18 to $32 \% \mathrm{~S}$. The affinity, however, of both serine, alanine and glutamic acid declined in $32 \%$ S. The Nereis spp. apparently compensate for this reduced affinity by increasing the absorption potential ( $V_{\max }$ ). A similar mechanism has been reported to occur in Enchytraeus albidus (Siebers and Bulnheim, 1977). As the amino acid uptake probably is interlinked with $\mathrm{Na}^{+}$transport across the epidermis (Anderson, 1975), the observed changes in affinity may not exclusively be found in amino acid transport mechanisms, but also in transport characteristics of $\mathrm{Na}^{+}$

Dynamics of the present amino acid uptake are difficult to relate to natural concentrations of amino acids or to intracellular pools of free amino acids. Thus, the high affinity to glutamic acid appears to be superfluous as natural glutamic acid concentrations often are relatively high (Jørgensen et al., 1980a, b); furthermore, glutamic acid only accounts for a few percent of the internal pool of free amino acids in the worms. In contrast, both affinity and natural concentration of alanine were low, while alanine was an important free amino acid in the Nereis spp. In addition, the increased uptake of serine in $32 \% \mathrm{~S}$ was not caused by an increased requirement for this amino acid as a free internal amino acid.

According to Gilles (1975), the composition of free amino acids in tissues of marine invertebrates demonstrates considerable changes in different salinities. In the Nereis spp., alanine, glycine and taurine were the most abundant free amino acids in both salinities. Lange (1963) found a linearity in salinity and in total content of free amino acids and taurine in the mussel Mytilus edulis. Contrary to this, our observations indicate an increasing, nonlinear significance of free amino acids in increasing salinities. This discrepancy may be due to changes in the concentration of proline which, according to Jeuniaux et al. (1961), is abundant in $N$. diversicolor. Proline was not determined in the present study. The importance of taurine in the Nereis spp. was less in $32 \% \mathrm{~S}$ than in $18 \% \mathrm{~S}$; correspondingly, the proportion of alanine was greater. We are uncertain if this observation is an experimental artifact. Some amino acids are essential to marine invertebrates, e. g. lysine (Gilles, 1975); if taurine is also essential to Nereis spp., its reduced percentage in $32 \%$ S may be due to an insufficient supply of taurine in the worms diet, as they were adapted to $32 \% \mathrm{~S}$ (from $18 \%$ S) during 3 weeks in sediment aquaria. We have not been able to find evidence for this in the literature.

The higher uptake rate of serine and partly of alanine in Nereis succinea, compared with $N$. virens and $N$. diversicolor, must probably be sought in the generally higher pools of free amino acids in this species. The present investigation does not demonstrate a correlation between natural concentrations of amino acids and uptake capacity in the Nereis spp. The observed variations in the free pools may rather be explained on the basis of different osmoregulatory strategies of the worms (Jeuniaux et al., 1961).

The extracted, free interstitial amino acids from Kysing Fjord sediment were sufficient to provide the Nereis spp. with a significant net influx of amino acids. As expected, the neutral amino acids glycine, alanine, and serine were predominantly reduced, but an unusually large uptake of glutamic acid also occurred. Uptake of glutamate and arginine was negligible in all species within the first hours, but after $4-6 \mathrm{~h}$ both were reduced, indicating that new amino acid-absorbing organisms (e.g. bacteria) may have appeared in the medium. These two amino acids may therefore be used as indicators of bacterial activity.

Simultaneously with amino acid absorption, a release took place. Experiments by Ahearn and Gomme (1975) showed that previously absorbed dissolved organics (D-glucose) are partly released in Nereis diversicolor. Concerning amino acids, these two processes probably occur independently, since released amino acids seem to originate in the excretion of nitrogeneous waste from the animals (Pandian, 1975). The present release experiments demonstrated that the concentration of some amino acids remained unchanged in the medium, while others accumulated. The ${ }^{14} \mathrm{C}$-experiments demonstrated that alanine, serine, and glutamic acid were simultaneously absorbed and released. The rather constant concentrations of some amino acids shown in Figure 9, e.g. alanine, threonine and glutamic acid, indicate equal release and uptake rates, whereas the increasing concentrations, e.g. of ornithine and lysine, might be caused by low uptake or fast release. If high bacteria concentrations were present at $21 \mathrm{~h}$, they were unable to reduce the ornithine. Environmental conditions, e.g. long periods of oxygen depletion, influence the release of amino acids in Nereis spp. (Jørgensen and Kristensen, 1980).

The flow-cell experiment suggests that ventilation in Nereis burrows also may have a nutritional aspect. If the interstitial water surrounding the worms is frequently replaced, these are continuously exposed to high interstitial amino acid concentrations. However, if the renewed water is transported from above the sediment, lower concentrations of amino acids are available to the worms. Actual concentrations of amino acids in worm burrows are presently being studied.

In the natural environment, Nereis spp. influence the prevalent concentrations of amino acids by (1) reducing ambient amino acids; (2) adding amino acids to the 
surrounding sea water. Flow experiments suggest that both processes probably occur continuously, at least for $48 \mathrm{~h}$ (Jørgensen, 1980). Most released amino acids are presumably immediately absorbed by organisms in the sediment. Others, like ornithine, may be of lower assimilative value to both bacteria and invertebrates, since this amino acid frequently occurs in high concentrations, compared to other amino acids, in marine sediments (Jørgensen et al., 1980a, b).

The extracted interstitial amino acids were of considerable quantitative importance to the Nereis spp. as their total metabolic energy expenditure was sustained from the uptake. Actively ventilating worms also obtained a significant benefit from absorption. Since Nereis spp. also obtain food by other modes of feeding, amino acids may be considered a valuable nutritive supplement. Similar observations of sediment-inhabiting animals were reported by Stephens (1975) and Stephens et al. (1978) in N. diversicolor and in the sand dollar Dendraster excentricus; both absorbed naturally occurring primary amines (mainly amino acids).

The concentrations of individual amino acids administered to the interstitial water in this study may not be identical to in-situ concentrations. During extraction, absorption of amino acids to sediment particles increases with increasing content of organic matter (Jørgensen et al., 1980b). The actual concentrations of free amino acids in the Nereis succinea sediment may, therefore, have been underestimated. Furthermore, our sediment cores were collected in winter, and need not represent concentrations of amino acids in periods with higher biological activities. Since a gentle extraction procedure was applied, the observed amino acids undoubtly represent the most easily available amino acids, i.e. amino acids being accessible to the Nereis species.

The dynamics of dissolved organic matter in marine environments are generally considered to be determined by autotrophic and heterotrophic microorganisms (Fenchel and Blackburn, 1979). The present observations emphasize, however, that invertebrates should be included when assimilation and turnover of dissolved organic matter are calculated.

Acknowledgements. We thank Dr. L. Cammen for criticism and suggestions. Skillful technical assistance was provided by $A$. Jensen. This study was supported by a grant from The University of Aarhus (to N. O. G. Jørgensen) and from The Danish Natural Science Research Council, grant No. 51115884 (chromatographic equipment).

\section{LITERATURE CITED}

Ahearn, G. A., Gomme, J. (1975). Transport of exogenous Dglucose by the integument of a polychaete worm (Nereis diversicolor Müller). J. exp. Biol, 62: 243-264
Anderson, J. W (1975). The uptake and incorporation of glycine by the gills of Rangia cuneata (Mollusca: Bivalvia) in response to variations in salinity and sodium. In: Vernberg, F. J. (ed.) Physiological ecology of estuarine organisms. University of South Carolina Press, Columbia, South Carolina, pp. 239-258

Anderson, J. W. Bedford, W B. (1973). The physiological response of the estuarne clam, Rangia cuneata (Gray), to salinity. Il. Uptake of glycine. Biol. Bull. mar biol. Lab., Woods Hole 144: 229-247

Blackburn, T H. (1979). Methods for measuring rates of $\mathrm{NH}_{4}^{+}$ turnover in anoxic marine sediments, using a ${ }^{15} \mathrm{~N}-\mathrm{NH}_{4}^{+}$ dilution technique. Appl. Microbiol. 37: 760-765

Fenchel, T., Blackburn, T H. (1979). Bacteria and mineral cycling, Academic Press, London

Gilles, R. (1975). Mechanism of ion and osmoregulation. In: Kinne, O (ed.) Marine ecology, Vol. II, Physiological mechanisms, Part 1. Wiley, London, pp. 259-347

Hobbie, J. E., Webb, K. L. (1968). Amino acid flux in an Estuary. Science, N. Y. 159: 1463-1464

Jeuniaux, Ch., Duchâteau-Bosson, Gh., Florkin, M. (1961). Variation de la Composante Amino-acide des Tissues et Euryhalinité chez Perinereis cultrifera Gr. et Nereis diversicolor (O. F. Müller). J. Biochem. 49: 527-531

Johannes, R. E., Webb, K. L. (1970). Release of dissolved organic compounds by marine and freshwater invertebrates. In: Hood, D. W (ed.) Symposium on organic matter in natural waters. Occasional Publication No. 1, Institute of Marine Science, University of Alaska, Alaska, pp. $257-273$

Jorgensen, C. B. (1976). August Pütter, August Krogh and modern ideas on the use of dissolved organic matter in aquatic environments. Biol. Rev. 51: 291-328

Jargensen, N. O. G. (1979). Uptake of L-valine and other amino acids by the polychaete Nereis virens. Mar. Biol. 52: $45-52$

Jørgensen, N. O. G. (1980). Uptake of glycine and release of primary amines by the polychaete Nereis virens (Sars) and the mud snail Hydrobia neglecta Muus. J. exp. mar. Biol. Ecol., in press

Jørgensen, N. O. G., Kristensen, E. (1980). Uptake of amino acids by three species of Nereis (Annelida: Polychaeta). II Effects of anaerobiosis. Mar. Ecol. Prog. Ser. 3: 341-346

Jorgensen, N. O. G., Mopper, K., Lindroth, P. (1980a). Occurrence, origin, and assimilation of free amino acids in an estuarine environment. Ophelia, in press

Jorgensen, N. O. G., Lindroth, P., Mopper, K. (1980b). Extraction of free amino acids and ammonia in sediments and overlaying sea waters from the Limfjord, Denmark. Submitted to Oecanologica Acta

Krom, M. D., Sholkovitz, E. R. (1977). Nature and reactions of dissolved organic matter in the interstitial waters of marine sediments. Geochim. cosmochim. Acta 41: $1565-1573$

Lange, R. (1963). The osmotic function of amino acids and taurine in the mussel Mytilus edulis. Comp. Biochem. Physiol. 10: 173-179

Lehninger, A. L. (1972). Biochemistry, Worth Publishers, Inc., New York

Lindroth, P., Mopper, K. (1979). Subpicomole, high performance liquid chromatographic determination of amino acids by precolumn fluorescence derivatization with ophthaldialdehyde. Analyt. Chem. 51: 1667-1674

Lopez, G., Riemann, F. Schrage, M. (1979). Feeding biology of the brackish-water oncholaimid nematode Adoncholaimus thalassophygas. Mar. Biol. 54: 311-318

Lyes, M. C. (1979). Bioavailability of a hydrocarbon from 
water and sediment to the marine worm Arenicola marina Mar. Biol. 55: 121-127

Muus, B. (1967). The fauna of Danish estuaries and lagoons. Meddr Kommn Danm. Fisk.- og Havunders. 5: 1-316

Neuhoff, H.-G. (1979). Influence of temperature and salinity on food conversion and growth of different Nereis species (Polychaeta, Annelida). Mar. Ecol. Prog. Ser 1:255-262

Pandian, T. J. (1975). Mechanisms of heterotrophy. In: Kinne, O. (ed.) Marine ecology, VoI. II, Physiological mechanisms, Part 1. Wiley, London, pp. 61-249

Siebers, D. (1979). Transintegumentary uptake of dissolved amino acids in the sea star Asterias rubens. A reassessment of its nutritional role with special reference to the significance of heterotrophic bacteria. Mar. Ecol. Prog. Ser. 1: 169-177

Siebers, D., Bulnheim, H.-P. (1977). Salinity dependence, uptake kinetics, and specificity of amino-acid absorption across the body surface of the oligochaete annelid Enchytraeus albidus. Helgoländer wiss. Meeresunters. 29: $473-492$

Smith, R. I. (1955). Comparison of the level of chloride regulation by Nereis diversicolor in different parts of its geographical range. Biol. Bull. mar, biol. Lab., Woods Hole 108: $326-345$

Southward, A. J., Southward, E. C. (1972). Observations on the role of dissolved organic compounds in the nutrition of benthic invertebrates. III. Uptake in relation to the organic content of the habitat. Sarsia 50: 29-46

Southward, A. J., Southward, E. C. (1979). Further experiments on the value of dissolved organic matter as food for
SibogInum fjordicum (Pogonophora). J. mar biol. Ass U. K. 59: $133-148$

Stephens, G. C. (1964). Uptake of organic material by marine invertebrates. Biol. Bull. mar. biol. Lab., Woods Hole 126 : $150-162$

Stephens, G. C. (1972). Amino acid accumulation and assimilation in marine organisms. In: Cambell, J. W., Goldstein, L. (eds) Nitrogen metabolism and the environment, Academic Press, London, pp. 155-184

Stephens, G. C. (1975). Uptake of naturally occurring primary amines by marine annelids. Biol. Bull. mar. biol. Lab., Woods Hole 149: 397-407

Stephens, G. C., Volk, M. J., Wright, S. H., Backlund, P. S. (1978). Transepidermal accumulation of naturally occurring amino acids in the sand dollar Dendraster excentricus. Biol. Bull. mar. biol. Lab., Woods Hole 154: 335-347

Strickland, J. D. H., Parsons, T. R. (1972). A practical handbook of sea water analysis, Fisheries Research Board of Canada, Ottawa

Taylor, A. G. (1969). The direct uptake of amino acids and other small molecules from sea water by Nereis virens Sars. Comp. Biochem. Physiol. 29: 243-250

Testerman, J. K. (1972). Accumulation of free fatty acids from sea water by marine invertebrates. Biol. Bull. mar. biol. Lab., Woods Hole 142: 160-177

Theede, H., Schaudinn, J., Saffé, F. (1973). Ecophysiological studies on four Nereis species of the Kiel Bay. Oikos 15 (Suppl.): $246-252$

Yonge, C. M. (1928). Feeding mechanisms in the invertebrates. Biol. Rev. 3: 21-76 